\section{Penning a patchwork}

Peter Kemp

The Whys of a Philosophical Scrivener.

By Martin Gardner.

William Morrow (Quill): 1983: Pp.452.

Hbk \$22.50; pbk \$12.95.

MARTIN Gardner owns, he says, some fifty books each by G.K. Chesterton and H.G. Wells; he subscribes to The Chestertonian Review and "used to take ... The Wellsian'". Further testifying to his avowed "fondness" for these writers, his pages are packed with admiring references to, and admired references from, them. More basically, his entire enterprise in The Whys of a Philosophical Scrivener writing as a jovial, voluble, at times almost self-parodyingly opinionated savant seems considerably indebted to them. That Gardner should emulate authors who, he feels, "have long been out of fashion" is part of his determinedly unmodish persona. Ostentatiously at variance with anything that might be thought meretriciously new-fangled, showing an almost cantankerous preference for those considered passé (William James is the philosopher most referred and deferred to), Gardner seems aptly published by Quill.

His quaint self-description as a "scrivener" presumably aims to match this robustly traditional image. A scrivener, though, was not an author but a copyist. And, in this sense, the word is more appropriate to Gardner's book than he may have intended. There is frequent reference to his "ffiles"; and the book often gives the impression of someone dipping into dossiers of approvingly transcribed passages. It does not so much sustain a thread of argument as loosely tack together pieces of reasoning - or rhetoric - from those Gardner esteems: "I agree with William James that . . .", "Let us listen ... to Unamuno", "here is Chesterton again".

This sometimes brings the book close to a patchwork anthology. And extracts, ripped out of context, can misleadingly represent their author. Garner's treatment of Wells is a case in point. As a selfproclaimed theist, he deplores Wells's emphatic godlessness. Attempting to alleviate it, he refers with some frequency to the fact that Wells "was once so taken by the concept of a finite God that he wrote an entire book about it, God the Invisible King'. What he doesn't make clear is that Wells harboured the notion only briefly, at a time of great nervous strain, during the First World War; that the God he envisaged was of a curiously belligerent cast - "as real as a bayonet thrust"; and that he was later shamefaced about his short period as a "theological Quisling".

Combining fairly recherché material God the Invisible King is rarely perused today - with an overriding theological drift, the technique is typical of Gardner. In his book, the "garnerings" of many years' wide reading bedeck an increasingly religious message: by the final chapter, readers are being urged to "Say something to God. Give thanks for something. Ask forgiveness for something." First sketching out his attitude towards truth, science, aesthetics, ethics, politics and economics, Gardner then devotes more than half as much space again to his feelings about God, prayer, evil, immortality. Mental gymnastics yield to the leap of faith. Mockery of current credulity about the paranormal gives way to spiritual affirmation: "I believe with my heart that God upholds all things".

Although possibly unexpected - "some readers", Gardner says, "may be surprised" at his theism - what emerges has a pattern. Expectably, in an admirer of Chesterton, Gardner relishes paradox. The unresolvable delights him. The epigraph to his book proclaims that "Philosophy is concerned with . . . soluble questions that are trivial, and crucial questions that are insoluble". And, as Gardner amply realizes, such crucial questions arise elsewhere, too. Quantum physics generates them. Some mathematical problems "can be 'solved' only by showing them to be unsolvable". In a way becoming popular, Gardner attempts to underpin theology with such insights. Applauding Godel's incompleteness theorem, he remarks that it "can hit one like a religious conversion, bringing with it a great liberation from anxiety ... I I sometimes fancy that God invaded Godel's mind (note the 'God' in his name)",

Initially, the book is characterized by a taste for both reasoning and the reasonable. Fascinated by logical intricacies, Gardner subscribes to straightforward opinions; philosophical acuity is allied to blunt commonsense. A noticeably favoured way of reaching his conclusions is to steer between extremes. In politicoeconomics, he makes for the extensive ground between Adam Smith and Karl Marx. When it comes to mapping out his religious creed, a similar procedure is adopted. Investing his credo with an air of sensible moderation, Gardner locates it between the crankily paranormal and the orthodoxly religious. Both of these opposing extremes are ones he is wellplaced to disparage knowledgeably. A keenness for assessing paranormal claims - from the Bermuda Triangle to "the power of the Great Pyramid's shape to preserve food and sharpen razor blades" - has given him rich instances of their poverty of conviction. Reared in an "ugly Protestant fundamentalism", he has a devastating knowledge of Biblical barbarity. Avoiding these outlandish extremes, his own dogma is, in many ways, as unexcitingly conventional as his political allegiances. Central to it is the familiar religious insistence on the limitations of the intellect. Religious faith, Gardner honestly emphasizes, is "belief unsupported by logic or science", a matter of emotional orientation: "emotional meanings play fundamental roles in decisions about philosophical questions". Behind Gardner's faith is hope. God, for him, "is essentially the provider of immortality".

As often, too, the nature of the deity revered reveals things about the worshipper. Characteristically, Gardner entertains speculations about a playful Provi- 
dence. Disposed to the waggish himself he attempts to trick the reader by coyly misattributed quotations; his favourite word is "whimsical"; he often refers delightedly to Frank L. Baum's Oz stories - he would clearly welcome a deity whose disposition is similar. Perhaps, he hopefully suggests, the universe is "a vast cosmic jest fabricated by a god who had no motive except to amuse himself and his friends". This cosy concept is discouraged, though, by memories from Gardner's fundamentalist education: God only laughs four times in the Bible; on each occasion, he is chortling over the fate of the damned.

Moving from the Old Testament to the new physics, jumbling quarks and quirks, Gardner's book is a weird blend of sophisticated cerebration and psychological naivety. In approach, it can be callow, full of sleeve-tuggings and leg-pullings. Being button-holed - "But wait! . . Perhaps, dear reader ..." - is a recurrent experience. Ratiocination roguishly collapses into an exaggerated throwing up of hands: "Is it true? Don't ask me. How could I possibly know? I put it forth whimsically". As much a wise guy as a "whys" man, Gardner can be alienatingly facetious - yet this doesn't stop his book from often being genuinely funny. Reverent gazings at the after-life co-exist with a sharp eye for the here and now. Political fatuities are savoured. And Gardner likes to pounce sardonically on Christian crassnesses - from the contemporary childishness of the born-again, carolling out that "Matthew 24 is Knocking at the Door" to medieval implements for uterine baptism of embryos. Oddly, a book introduced as simply "about what I believe and why" is at its keenest when debunking the bizarre beliefs of others.

Peter Kemp is Senior Lecturer in English at the MiddlesexPolytechnic, London. He is author of H.G. Wells and the Culminating Ape (Macmillan, 1982).

Who got where when

Nicholas Wade

Exploring the Earth and the Cosmos.

By Isaac Asimov.

Crown/Allen Lane: 1982.

Pp.352. \$13.95, £8.95.

ACCORDING to the dustflap of this book, Isaac Asimov's two-hundredth book was published in 1979. The present work is doubtless his 210 th, a fact that must make any reviewer lay aside, at least for a few seconds, the pose of omniscient scorn his kind is obliged to affect. A writer who has published 200 popular books is certainly a master of his craft, like it or not.

Exploring the Earth and the Cosmos is a craftsmanlike compendium of the history of geographical and extraterrestrial exploration. It is taut with pertinent facts, lucidly and deftly presented. It tells you the temperature of the planet Mercury, the distance to Alpha Centauri, the height of many great mountains and the depths of many profound abysses. It relates, with Guinness Book of Records exactitude, who got where first.

In this connection, Asimov may perhaps be a little too clement to the claims explorers make. He cites Admiral Peary as the first man to reach the North Pole, and since Encyclopaedia Britannica does likewise, he shall not be faulted for that. The astronomer Dennis Rawlins, however, showed in a book of 1973 that there is strong reason to doubt the good Admiral ever went near the pole. Since explorers tend to have few independent witnesses, but patrons and a public to satisfy, their claims often merit some scepticism.

It is here perhaps that Mr Asimov's relentless march of facts begins to provoke a twinge of fatigue in the reader. At some point people become more interesting than things to even the most hardened misanthrope. Someone had to be first to the North Pole; who cares if it was Admiral Peary or Eeyore? But if Admiral Peary was spinning a yarn, that's a story that can be sat up for. Similarly the Venetian master Titian is earnestly cited for his longevity, but Titian was not the first to let his anticipation of a pension outweigh his appetite for factual exactitude. Modern scholars believe he was born in 1488, not 1477 as Titian and Asimov declare.

Expansion of physical horizons is the theme that threads the book together. $\mathrm{Mr}$ Asimov concludes by noting that "there are other horizons that have expanded magnetic intensity, viscosity, angular momentum, etc - but those I have present are sufficient to show humanity at its most magnficently human ..." The observation evokes the image of someone swimming through molasses in a 5 tesla field at $33 \mathrm{~g}$, which would surely be as fine a testament as any to the human side of humanity. The weakness of the book is that Mr Asimov's interest in facts is inexhaustible, his attention to motive exiguous. Yet without motive, who would ever leave home to go exploring either Earth or cosmos?

Inclusion of the details that interest historians, however, would have extended the book beyond any reasonable scope. $\mathrm{Mr}$ Asimov's aim was to distill the quintessence of fact, and he has succeeded excellently. Yet the book is probably one that more people will find useful as a work of reference than will read for pleasure.

Nicholas Wade is an editorial writer on the New York Times and co-author of Betrayers of the Truth (Century, 1983), an analysis of fraud in science.

\section{Smoothing the flow of data}

\author{
T.A. Kletz
}

How to Write and Publish a Scientific

Paper, 2nd edn.

By Robert A. Day.

ISI Press: 1983. Pp.180. Hbk \$17.95; pbk \$11.95.

MANY who have to read scientific papers, reports and memoranda, published and unpublished, will have sympathized with the chairman of a recent Inquiry, who wrote in his report, of the written evidence he had received, "Turgid and indigestible as some of it was, the Assessor and I read it, though often with little profit". Many scientific and technical reports are badly written. (Is this why so few technologists seem to read books for pleasure? Does the garbage they have to read put them off all reading?) I therefore turned hopefully to the new edition of Day's book. Could I recommend it to colleagues, past and present? It is well-written, it was a pleasure to read (I must get my tenses right), it contains many amusing anecdotes, but a better title would be 'All you need to know about writing a scientific paper except what words to use' or 'How to make life easier for editors'

This book covers choice of title, the abstract, the manuscript, the diagrams, layout of tables, references, proofchecking, ordering reprints and other such matters but only two short chapters deal with the actual choice of words. The author claims that if you organize the paper properly it will write itself, but this is not so. You could follow all his advice (except for the two chapters I have mentioned) and produce an unreadable paper; you could ignore all his advice and produce a paper that is a pleasure to read and which influences its readers, even though the tables take up more room than they need and the references are a mess. In fact, Day like many editors, almost forgets that it is the content that makes a paper and not the layout.

There is no reason why authors should not follow his advice and make his life easier - it is sloppy to have references arranged inconsistently, for example but readers are (we hope) more numerous than editors and it is therefore more important to make their life easier by developing a clear style, particularly if you are writing for a wider public. Fellow workers in your field may persevere; others will not.

Day paints a picture of the editor as a man martyred by authors who will not follow his advice. As an author I do not quite see it that way; it is me (or my papers) that are afflicted. I could quote many examples of editors who have changed what they did not understand, shortened 